\title{
Influence of the support on rhodium speciation and catalytic activity of rhodium-based catalysts for total oxidation of methane
}

Zhang, Yu; Glarborg, Peter; Andersson, Martin Peter; Johansen, Keld; Torp, Thomas Klint; Jensen, Anker Degn; Christensen, Jakob Munkholt

\section{Published in:}

Catalysis Science and Technology

Link to article, DOI:

10.1039/d0cy00847h

Publication date:

2020

Document Version

Peer reviewed version

Link back to DTU Orbit

Citation (APA):

Zhang, Y., Glarborg, P., Andersson, M. P., Johansen, K., Torp, T. K., Jensen, A. D., \& Christensen, J. M. (2020). Influence of the support on rhodium speciation and catalytic activity of rhodium-based catalysts for total oxidation of methane. Catalysis Science and Technology, 10(17), 6035-6044.

https://doi.org/10.1039/d0cy00847h

\section{General rights}

Copyright and moral rights for the publications made accessible in the public portal are retained by the authors and/or other copyright owners and it is a condition of accessing publications that users recognise and abide by the legal requirements associated with these rights.

- Users may download and print one copy of any publication from the public portal for the purpose of private study or research.

- You may not further distribute the material or use it for any profit-making activity or commercial gain

- You may freely distribute the URL identifying the publication in the public portal 


\section{Influence of the support on rhodium}

2 speciation and catalytic activity of rhodium-

3 based catalysts for total oxidation of

4 methane

5

6

7

8 Yu Zhang ${ }^{1}$, Peter Glarborg ${ }^{1}$, Martin Peter Andersson ${ }^{1}$, Keld Johansen ${ }^{2}$, Thomas Klint Torp ${ }^{2}$, Anker

9 Degn Jensen ${ }^{1}$, Jakob Munkholt Christensen ${ }^{1 *}$

$10{ }^{1}$ Department of Chemical and Biochemical Engineering, Technical University of Denmark (DTU),

11 Søltofts Plads 229, 2800 Kgs. Lyngby, Denmark.

$12{ }^{2}$ Haldor Topsoe A/S, Haldor Topsøes Allé 1, 2800 Kgs. Lyngby, Denmark

13 *email: jmc@kt.dtu.dk 


\section{Abstract}

15 The role of the support in $\mathrm{Rh}$-based catalysts for total oxidation of $\mathrm{CH}_{4}$ was investigated using both amorphous $\mathrm{SiO}_{2}$ and $\gamma-\mathrm{Al}_{2} \mathrm{O}_{3}$ as well as ZSM-5 and SSZ-13 zeolites with varying $\mathrm{SiO}_{2} / \mathrm{Al}_{2} \mathrm{O}_{3}$ ratios. The methane oxidation activity was measured in both presence and absence of 5 vol. $\% \mathrm{H}_{2} \mathrm{O}$ and $20 \mathrm{ppm}$ $\mathrm{SO}_{2}$. The support had a strong impact on the $\mathrm{Rh}$ speciation $\left(\mathrm{Rh}_{2} \mathrm{O}_{3}\right.$ nanoparticles vs. single $\mathrm{Rh}$ atom sites), which was important for the activity, as the nanoparticle sites were found to be far more active than the single atom sites. A 2 wt. $\% \mathrm{Rh} / \mathrm{ZSM}-5\left(\mathrm{SiO}_{2} / \mathrm{Al}_{2} \mathrm{O}_{3}=280\right)$ catalyst with $\mathrm{Rh}$ exclusively as $\mathrm{Rh}_{2} \mathrm{O}_{3}$ nanoparticles was able to provide oxidation at a $75{ }^{\circ} \mathrm{C}$ lower temperature than an ion-exchanged 0.294 wt.\% $\mathrm{Rh} / \mathrm{ZSM}-5\left(\mathrm{SiO}_{2} / \mathrm{Al}_{2} \mathrm{O}_{3}=30\right)$ catalyst with $\mathrm{Rh}$ exclusively as single atoms despite a similar concentration of active sites in the two samples. All catalysts were inhibited by the presence of water, but this inhibition was particularly strong for an amorphous $\mathrm{SiO}_{2}$ support and for the most Al-rich zeolites and less severe for $\mathrm{Si}$-rich zeolites. The inhibition from $\mathrm{SO}_{2}$ was relatively stronger for the more Al-rich supports, which was attributed to an uptake of sulfur at Al sites that was detrimental to the performance of the active phase. In a realistic gas atmosphere containing both $\mathrm{H}_{2} \mathrm{O}$ and $\mathrm{SO}_{2} \mathrm{Si}$-rich ZSM-5 $\left(\mathrm{SiO}_{2} / \mathrm{Al}_{2} \mathrm{O}_{3}=280\right)$ therefore emerged as the best support. This was because the low acidity ensured minimal loss of $\mathrm{Rh}$ to the less active single atom sites, avoidance of the detrimental sulfur uptake by the support seen for more Al-rich supports, and avoidance of the strong water induced inhibition that occurs for amorphous $\mathrm{SiO}_{2}$ and $\mathrm{Al}$-rich zeolites.

Keywords: rhodium, support, nanoparticles, single atoms, $\mathrm{CH}_{4}$ oxidation. 


\section{Introduction}

Natural gas engines have the advantage of low $\mathrm{NO}_{\mathrm{x}}, \mathrm{SO}_{\mathrm{x}}$ and particulates emissions, which makes them interesting for applications such as maritime transport, but the slip of $\mathrm{CH}_{4}$ from lean-burn natural gas engines causes environmental problems due to the high greenhouse gas potential of $\mathrm{CH}_{4}$ (26-38 times that of $\left.\mathrm{CO}_{2}\right) \cdot{ }^{1-3}$ Mitigation of the $\mathrm{CH}_{4}$ slip by catalytic oxidation of $\mathrm{CH}_{4}$ in the exhaust gas is therefore necessary.

The exhaust gas from lean-burn natural gas fired engines is characterized by intermediate temperatures $\left(350-540{ }^{\circ} \mathrm{C}\right)$, excess of $\mathrm{O}_{2}\left(\sim 10\right.$ vol.\%) and presence of both $\mathrm{H}_{2} \mathrm{O}\left(5-10\right.$ vol.\%) and $\mathrm{SO}_{2}$ (up to $1 \mathrm{ppm}$ ). ${ }^{4,5}$ Complete removal of $\mathrm{CH}_{4}$ under dry and sulfur-free conditions is facile using Pd based catalysts, which are acknowledged as the most active catalysts for $\mathrm{CH}_{4}$ oxidation. ${ }^{6-8}$ However, the presence of $\mathrm{H}_{2} \mathrm{O}$ and especially the combined presence of $\mathrm{H}_{2} \mathrm{O}$ and $\mathrm{SO}_{2}$ is strongly detrimental for $\mathrm{Pd}$ based catalysts. ${ }^{9-12}$ Recent work found that Rh based catalysts show better performance for $\mathrm{CH}_{4}$ oxidation in atmospheres containing both $\mathrm{H}_{2} \mathrm{O}$ and $\mathrm{SO}_{2} \cdot{ }^{13}$ The conversion of $\mathrm{CH}_{4}$ over a $\mathrm{Rh} / \mathrm{ZSM}$ $5\left(\mathrm{SiO}_{2} / \mathrm{Al}_{2} \mathrm{O}_{3}=280\right)$ catalyst could be maintained at $58-79 \%$ in the presence of 5 vol. $\% \mathrm{H}_{2} \mathrm{O}$ and $1 \mathrm{ppm}$ $\mathrm{SO}_{2}$ at engine achievable exhaust gas temperatures $\left(475-500{ }^{\circ} \mathrm{C}\right)$ and a high gas hourly space velocity (GHSV, $\left.150,000 \mathrm{~mL} /\left(\mathrm{g}_{\mathrm{cat}} \cdot \mathrm{h}\right)\right) .{ }^{13-15}$ The benefit of $\mathrm{Rh}$ was attributed to $\mathrm{H}_{2} \mathrm{O}$ partly alleviating the $\mathrm{SO}_{2}$ poisoning by destabilizing the $\mathrm{Rh}$ sulfate hydrates, which allowed a partial sulfur release at low temperatures.

Our previous work ${ }^{13}$ identified $\mathrm{Rh}_{2} \mathrm{O}_{3}$ nanoparticles to be the active phase for $\mathrm{CH}_{4}$ oxidation, which follows the Mars-van Krevelen type mechanism involving structural oxygen in the rhodium oxide surface. ${ }^{16}$ In optimization of the catalytic activity, which is of particular importance for catalysts relying on expensive noble metals, the identification of the optimal support is of central importance. It is therefore highly relevant to evaluate how the novel Rh-based oxidation catalysts depend upon the support. Previously zeolite-based support materials with varying $\mathrm{SiO}_{2} / \mathrm{Al}_{2} \mathrm{O}_{3}$ ratios have shown good performance in $\mathrm{Cu}$ catalysts for $\mathrm{NH}_{3}$-SCR as well as in $\mathrm{Pd}$ catalysts for $\mathrm{CH}_{4}$ oxidation. ${ }^{17-20} \mathrm{~A}$ high concentration of zeolite exchange sites, obtained using low $\mathrm{SiO}_{2} / \mathrm{Al}_{2} \mathrm{O}_{3}$ ratio zeolites, was found to favor 
the dispersion of Pd into smaller nanoparticles thereby improving the initial activity. ${ }^{6,21}$ On the other hand, Pd supported on Si-rich zeolites was reported to be more stable and more sulfur tolerant. ${ }^{18,22}$ The optimal acidity of the zeolite could thus be the one that strikes a balance between dispersion/initial activity at higher acidity and better stability/weaker interaction with inhibitors at lower acidity. The level of zeolite acidity giving the optimal performance for the Rh-catalyzed total oxidation of methane should therefore be identified. On a zeolite support the active phase can take the form of both continuous phases and single atoms at the zeolite exchange sites. Among the continuous phases it can be difficult to fully distinguish if the amorphous $\mathrm{Rh}_{2} \mathrm{O}_{3}$ structure is in the form of nanoparticles or films. Here we have mainly used the term nanoparticles throughout the text. Rh on a zeolite support was studied for partial oxidation of $\mathrm{CH}_{4}$ to acetic acid and methanol, and single $\mathrm{Rh}$ atom sites were correlated to higher selectivity to the partial oxidation products. ${ }^{23,24}$ A superiority of Rh catalysts with single atom sites were also reported for the water gas shift reaction. ${ }^{25,26}$ Single $\mathrm{Rh}$ atom sites will provide the optimal utilization of the active phase, but their activity for total oxidation is unknown. To clarify the importance of single atom sites for total oxidation it is important to study the influence of the support on the distribution between single Rh atoms and nanoparticles. This distribution can be characterized by diffuse reflectance infrared Fourier transform spectroscopy (DRIFTS) measurements on chemisorbed CO, since CO bonds differently to Rh single atom sites and nanoparticle sites..$^{27-29}$

In this work, a variety of ZSM-5 MFI zeolites with Si/Al = $15-140$ and an SSZ-13 CHA zeolite with $\mathrm{Si} / \mathrm{Al}=12$ were studied as support materials for $\mathrm{Rh}$ in order to realize different $\mathrm{Rh}$ site distributions and compared to amorphous $\mathrm{SiO}_{2}$ and $\gamma-\mathrm{Al}_{2} \mathrm{O}_{3}$ supports. Rhodium was deposited by impregnation or ion-exchange techniques. The site distribution (i.e. single atom sites vs. nanoparticle sites) was analyzed by CO-DRIFTS and the presence of $\mathrm{Rh}_{2} \mathrm{O}_{3}$ nanoparticles was also evaluated by X-ray Diffraction (XRD) and Transmission Electron Microscopy (TEM). The activity of the prepared Rh based catalysts towards $\mathrm{CH}_{4}$ oxidation was tested in different reaction atmospheres in a fixed-bed plug flow reactor. The sulfur tolerance of the catalyst was correlated to the site distribution to identify the optimal Rh catalyst for $\mathrm{CH}_{4}$ oxidation under realistic engine exhaust gas conditions where both $\mathrm{H}_{2} \mathrm{O}$ and $\mathrm{SO}_{2}$ are present. 


\section{Experimental methods}

\subsection{Materials}

Rhodium (III) nitrate hydrate $\mathrm{Rh}\left(\mathrm{NO}_{3}\right)_{3}{ }^{*} \mathrm{xH}_{2} \mathrm{O}(\sim 36$ wt.\% Rh basis, Sigma Aldrich) was used as precursor for the catalyst preparation. ZSM-5 with Si/Al molar ratios of $140\left(\mathrm{SiO}_{2} / \mathrm{Al}_{2} \mathrm{O}_{3}=280, \mathrm{CBV}\right.$ 28014), $40\left(\mathrm{SiO}_{2} / \mathrm{Al}_{2} \mathrm{O}_{3}=80, \mathrm{CBV} 8014\right), 25\left(\mathrm{SiO}_{2} / \mathrm{Al}_{2} \mathrm{O}_{3}=50, \mathrm{CBV} 5524 \mathrm{G}\right)$ and $15\left(\mathrm{SiO}_{2} / \mathrm{Al}_{2} \mathrm{O}_{3}=30\right.$, CBV 3014) were obtained from Zeolyst International. SSZ-13 with a Si/Al ratio of $12\left(\mathrm{SiO}_{2} / \mathrm{Al}_{2} \mathrm{O}_{3}=24\right)$ was supplied by Haldor Topsoe. Presently, the zeolites are named ZSM-5(X) and SSZ-13(X) with X denoting the $\mathrm{SiO}_{2} / \mathrm{Al}_{2} \mathrm{O}_{3}$ ratio. The amorphous support materials $\mathrm{SiO}_{2}(\mathrm{SS} 61138)$ and $\gamma-\mathrm{Al}_{2} \mathrm{O}_{3}(\mathrm{SA} 6175)$ were obtained from Saint-Gobain.

\subsection{Catalyst preparation}

$2 \mathrm{wt.} \% \mathrm{Rh}$ based catalysts were prepared by the incipient wetness impregnation (IWI) method followed by calcination in flowing air at $600{ }^{\circ} \mathrm{C}$ for $6 \mathrm{~h}$ as described elsewhere. ${ }^{13} \mathrm{~A}$ catalyst with only single atom Rh sites was prepared by an ion exchange (IE) method with ZSM-5(30) zeolite as support material. Here $0.1111 \mathrm{~g}$ rhodium (III) nitrate hydrate (giving $0.04 \mathrm{~g} \mathrm{Rh}$ ) was added to a beaker with $100 \mathrm{ml}$ deionized water, and $1.96 \mathrm{~g}$ ZSM-5(30) powder was then added. The mixture was stirred at room temperature for 24 hours followed by washing with deionized water until the $\mathrm{pH}$ of the filtrate was neutral. The filter cake was then dried at $80{ }^{\circ} \mathrm{C}$ to remove the moisture. The sample was then subjected to a second, identical ion-exchange step followed by washing and drying. Finally the ion exchanged catalyst was calcined in flowing air at $600{ }^{\circ} \mathrm{C}$ for $6 \mathrm{~h}$. Because of texture changes after impregnation or ion exchange, the calcined catalysts were ground, pelletized, crushed, and sieved again to $150-300 \mu \mathrm{m}$. The catalysts prepared by IWI were named 2 wt.\% Rh/support, e.g. 2 wt.\% Rh/ZSM-5(280), and the $\mathrm{Rh}$ catalyst prepared by ion exchange was named Rh/ZSM-5(30)-IE. The calcined samples were used for characterization and catalytic tests without any further degreening treatments. Tests of stability as a function of time on stream are presented in the supporting information. 


\subsection{Catalyst characterization}

115 XRD patterns of the fresh catalysts were measured using a Panalytical XPert Pro instrument system in

116 Bragg-Brentano geometry working in reflectance mode with $\mathrm{Cu} \mathrm{K} \alpha$ as radiation source $(1.54056 \AA$, 40

$117 \mathrm{kV}$ and $40 \mathrm{~mA}$ ). The investigated $2 \theta$ range was $5-70^{\circ}$ with a step size of $0.017^{\circ}$.

118 The distribution of $\mathrm{Rh}$ between $\mathrm{Rh}$ nanoparticle sites and single atom sites was determined by 119 DRIFTS measurements of $\mathrm{CO}$ chemisorbed at $25^{\circ} \mathrm{C}$ on the oxidized form of the catalyst. The details of the instrument have been described elsewhere. ${ }^{13,30}$ The spectra were obtained by averaging 76 scans at a resolution of $4 \mathrm{~cm}^{-1}$. Catalyst samples in the fresh oxide form were diluted with $\mathrm{KBr}$ (FTIR grade, Sigma-Aldrich) particles and loaded into the chamber. Before dosage of $\mathrm{CO}$, the background spectrum was collected in $\mathrm{He}$ at $25{ }^{\circ} \mathrm{C}$. Then $\mathrm{CO}$ was introduced to the sample by mixing $9.5 \mathrm{vol} . \% \mathrm{CO}$ in $\mathrm{Ar}$ (AGA Industrial Gas Denmark) and He (Air Liquide Denmark), giving a CO concentration in the range of $0-5000 \mathrm{ppm}$. The spectra were collected during both $\mathrm{CO}$ chemisorption and $\mathrm{He}$ flush. The concentration of $\mathrm{CO}$ was increased stepwise until no changes in the spectra were observed indicating saturation of the surface. After chemisorption the CO flow was switched off, and the spectra were collected during He flush until no further change in the spectra occurred. On both isolated single atom sites and on $\mathrm{Rh}_{2} \mathrm{O}_{3}$ oxide nanoparticles $\mathrm{CO}$ adsorption is expected to result in $\mathrm{Rh}(\mathrm{CO})_{2}$ dicarbonyl species. $^{24,31-33}$ The symmetric and asymmetric $\mathrm{CO}$ stretches of $\mathrm{Rh}$ carbonyls $\mathrm{Rh}(\mathrm{CO})_{2}$ on isolated $\mathrm{Rh}$ single atoms are labelled as $\mathrm{a}_{\mathrm{s}}$ and $\mathrm{a}_{\mathrm{a}}$, and the symmetric and asymmetric $\mathrm{CO}$ stretches of $\mathrm{Rh}(\mathrm{CO})_{2}$ on $\mathrm{Rh}_{2} \mathrm{O}_{3}$ nanoparticles are labelled as $b_{s}$ and $b_{a}$ throughout this work. The last spectrum during the $\mathrm{He}$ flush was used to determine the ratio between single atom $\mathrm{Rh}$ sites and nanoparticle $\mathrm{Rh}$ sites according to Eq. 1.

$$
\frac{\operatorname{Rh}(C O)_{2, S A}}{\operatorname{Rh}(\mathrm{CO})_{2, N P}}=\frac{\mathrm{A}_{a_{s}}}{\mathrm{~A}_{b_{s}}}
$$

Here $\mathrm{A}_{a_{s}}$ is the peak area of the symmetric stretch of $\mathrm{Rh}$ single atom bonded carbonyls, $\mathrm{Rh}(\mathrm{CO})_{2, \mathrm{SA}}$, 
analysis is based on the two strongest bands, which lowers uncertainty, and as the extinction coefficients of the two IR modes are not too dissimilar (less than a factor of 3 ) ${ }^{25}$ this ratio should give a reasonable estimate of the site ratio.

The Rh loading of Rh/ZSM-5(30)-IE catalyst was determined by inductively coupled plasma optical emission spectroscopy (ICP-OES) with an Agilent 720 ES ICP-OES. Here $0.1 \mathrm{~g}$ finely ground catalyst and $4 \mathrm{~g}$ finely ground $\mathrm{Na}_{2} \mathrm{O}_{2}$ (pro analysis quality) were mixed thoroughly and transferred quantitatively into a zirconium crucible in duplicate. The sample was heated to $500{ }^{\circ} \mathrm{C}$ for 4 hours in a muffle furnace. After cooling, the fusion cake was dissolved in pure water (18.2 M $\Omega$ ) and the zirconium crucible was leached with $10 \mathrm{ml} 37 \% \mathrm{HCl}$ (pro analysis quality) three times with gentle heating. The sample solution was then transferred to a $200 \mathrm{ml}$ volumetric flask and filled to the mark with pure water (18.2 M $\Omega$ ). The sample solution was analyzed by ICP-OES with two to five times further dilution and the emission signal from several Rh specific emission lines were compared to the signal from certified and matrix matched calibration standards containing $0-1 \mathrm{mg} / \mathrm{L} \mathrm{Rh}$. The relative precision of the analysis is estimated to $\pm 5 \%$.

The morphology and distribution of Rh on fresh and spent Rh catalysts were analyzed with Talos F200X analytical (S)TEM equipped with a new advanced energy dispersive X-ray spectroscopy (EDS). The High Angle Annular Dark Field (HAADF) detector was used to acquire pictures. The EDS was complimented by an Electron Energy Loss Spectroscopy (EELS) system with $0.7 \mathrm{eV}$ energy resolution for image filtering (EFTEM) and quantitative analysis of the sample elements.

\section{4 $\mathrm{CH}_{4}$ oxidation activity measurement}

The activity of the $\mathrm{Rh}$ based catalyst in the temperature range of $250-600{ }^{\circ} \mathrm{C}$ in different atmospheres (as listed in Table 1) were measured using a fixed-bed plug-flow quartz reactor placed in a furnace with three heating zones (top, middle, and bottom) described in more detail elsewhere. ${ }^{13} \mathrm{~A}$ fresh catalyst sample was loaded for the measurement in each gas atmosphere. For each test, $0.12 \mathrm{~g}$ of catalyst was weighed and diluted by $1.08 \mathrm{~g}$ inert sand to give a total bed mass of $1.20 \mathrm{~g}$. The catalyst and sand 


\begin{tabular}{llllll}
\hline \multirow{5}{*}{ Concentrations } & & \\
\cline { 2 - 6 } Atmospheres & $\mathrm{CH}_{4}(\mathrm{ppm})$ & $\mathrm{O}_{2}$ (vol.\%) & $\mathrm{H}_{2} \mathrm{O}$ (vol.\%) & $\mathrm{SO}_{2}(\mathrm{ppm})$ & $\mathrm{N}_{2}$ (vol.\%) \\
\hline Rea-1 & 2500 & 10 & $/$ & $/$ & Rest \\
Rea-2 & 2500 & 10 & 5 & $/$ & Rest \\
Rea-3 & 2500 & 10 & 5 & 20 & Rest \\
\hline
\end{tabular}

Here $\left[\mathrm{CH}_{4}\right]_{\text {in }}$ is the inlet $\mathrm{CH}_{4}$ concentration measured during bypass of the reactor and $\left[\mathrm{CH}_{4}\right]_{\text {out }}$ is the outlet $\mathrm{CH}_{4}$ concentration. In these experiments the only products of $\mathrm{CH}_{4}$ oxidation were $\mathrm{CO}_{2}$ and $\mathrm{H}_{2} \mathrm{O}$ and the carbon balance $(\mathrm{CB})$ was within $\pm 2 \%$ for all the activity tests.

Table 1. List of reaction atmospheres for oxidation of $\mathrm{CH}_{4}$.

The temperature programs for the activity measurement for $\mathrm{CH}_{4}$ oxidation in different atmospheres are shown in Fig. 1. Measurements were made during both heating and subsequent cooling, and throughout the text the heating is termed the $1^{\text {st }}$ run, whereas the subsequent cooling is termed the $2^{\text {nd }}$ run. Under dry and $\mathrm{SO}_{2}$ free conditions (Rea-1), the activity during the $1^{\text {st }}$ run was measured at steady-state conditions at each temperature and during the $2^{\text {nd }}$ run was measured at transient conditions as shown in Fig. 1 (a). In the presence of 5 vol. $\% \mathrm{H}_{2} \mathrm{O}$ (Rea-2), an extra stability test at $475{ }^{\circ} \mathrm{C}$ for $15 \mathrm{~h}$ was carried 
out in the $2^{\text {nd }}$ run during cooling (Fig. 1 (b)). With both 5 vol. $\% \mathrm{H}_{2} \mathrm{O}$ and $20 \mathrm{ppm} \mathrm{SO}_{2}$ present (Rea-3), both the $1^{\text {st }}$ and $2^{\text {nd }}$ runs were measured under steady-state conditions, and extra $15 \mathrm{~h}$ stability tests were carried out at $450{ }^{\circ} \mathrm{C}$ during heating and at $500{ }^{\circ} \mathrm{C}$ during cooling (Fig. 1 (c))
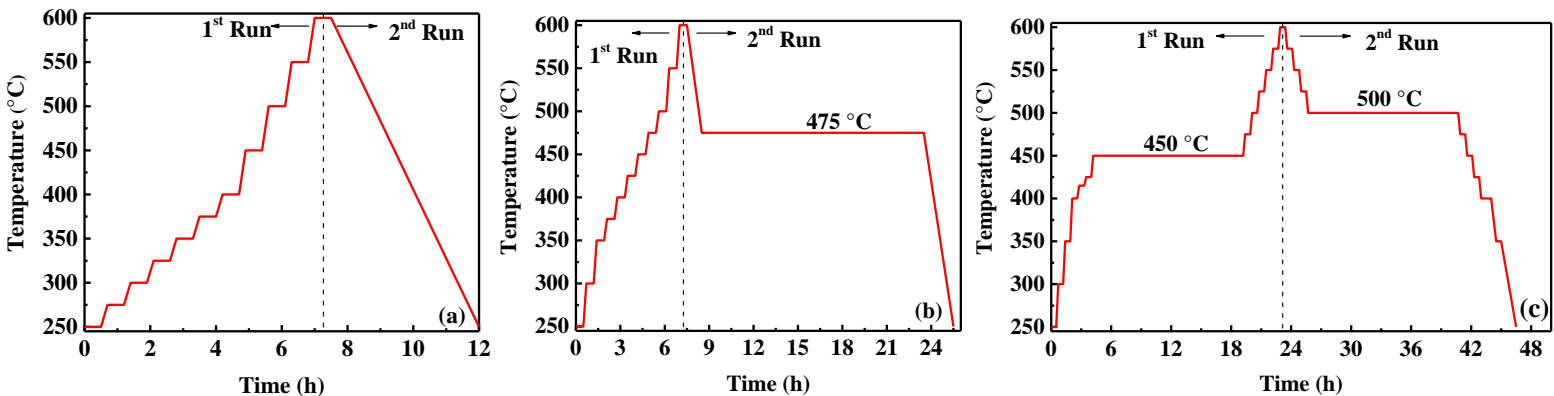

Fig. 1. Temperature programs for the $\mathrm{CH}_{4}$ oxidation activity test in (a): $2500 \mathrm{ppm} \mathrm{CH}_{4}+10$ vol.\% $\mathrm{O}_{2}$, (b): 2500 ppm $\mathrm{CH}_{4}+10$ vol. $\% \mathrm{O}_{2}+5$ vol. $\% \mathrm{H}_{2} \mathrm{O}$, and (c): $2500 \mathrm{ppm} \mathrm{CH}_{4}+10$ vol. $\% \mathrm{O}_{2}+5$ vol. $\%$ $\mathrm{H}_{2} \mathrm{O}+20 \mathrm{ppm} \mathrm{SO}$, balanced with $\mathrm{N}_{2}, \mathrm{GHSV}=150,000 \mathrm{NmL} /\left(\mathrm{g}_{\text {cat }} \cdot \mathrm{h}\right)$. Figure reproduced with permission from Zhang et al. ${ }^{13}$. Copyright 2020, American Chemical Society.

\section{Results and discussion}

\subsection{Characterization of the fresh catalysts}

The results of XRD analyses for the supported Rh catalysts and the pure support materials are shown in Fig. 2 (a)-(f). The XRD patterns of the pure supports confirmed the MFI structure of all ZSM-5 samples, the CHA structure of SSZ-13(24), and the amorphous nature of $\mathrm{SiO}_{2}$ and $\gamma-\mathrm{Al}_{2} \mathrm{O}_{3}$. The impregnation of Rh did thus not change the structure of the support. The Rh catalysts contain welldispersed $\mathrm{Rh}_{2} \mathrm{O}_{3}$, which is largely amorphous on all the supports. Previous analyses of spent catalysts have also suggested that this oxide form is the working state of the catalyst at the presently used oxygen rich reaction conditions. ${ }^{13}$ The XRD pattern of Rh/ZSM-5(30)-IE is shown in Fig. S1 in the Supporting Information and it is identical to the pure ZSM-5(30) support, but ICP-OES does reveal a Rh content of $0.294 \pm 0.015 \mathrm{wt} . \%$ indicating that the $\mathrm{Rh}$ is in a highly dispersed state invisible to XRD. 

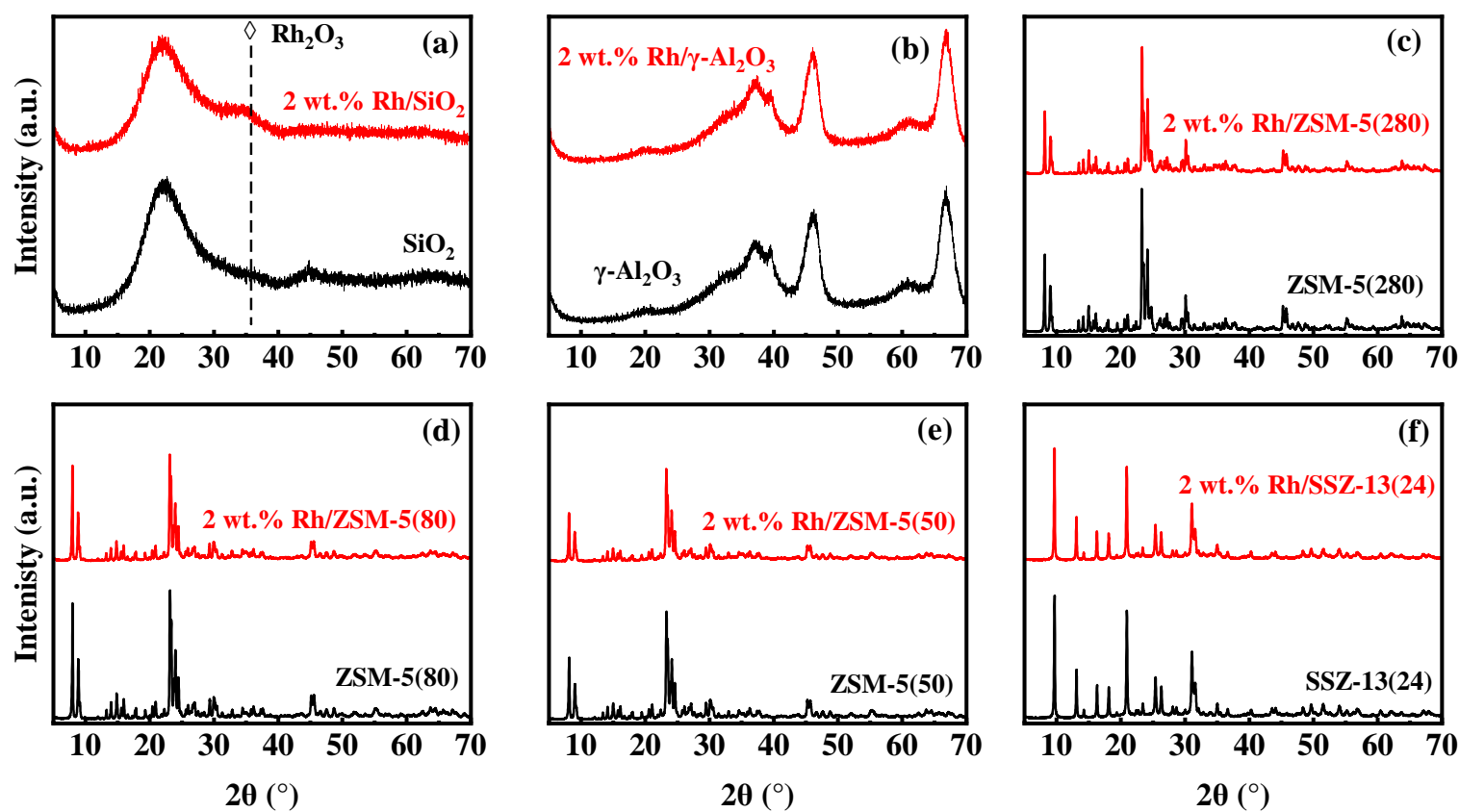

203

Fig. 2. XRD patterns of the pure support and 2 wt. $\%$ Rh catalysts on (a): $\mathrm{SiO}_{2},(b): \gamma-\mathrm{Al}_{2} \mathrm{O}_{3}$, (c): $\mathrm{ZSM}$ 5(280), (d): ZSM-5(80), (e): ZSM-5, and (f): SSZ-13(24). Data for $\mathrm{Rh} / \mathrm{SiO}_{2}, \mathrm{Rh} / \gamma-\mathrm{Al}_{2} \mathrm{O}_{3}$, and $\mathrm{Rh} / \mathrm{ZSM}-5(280)$ from Zhang et al. ${ }^{13}$.

The HAADF-STEM images of 2 wt.\% Rh/ZSM-5(280) and Rh/ZSM-5(30)-IE are shown in Fig. 3 and the corresponding EDS maps are shown in Fig. 4. $\mathrm{Rh}_{2} \mathrm{O}_{3}$ nanoparticles $(\sim 20 \mathrm{~nm})$ as a separate phase outside the zeolite structure could be observed for 2 wt.\% Rh/ZSM-5(280) (Fig. 3 (a)). Oppositely, no continuous $\mathrm{Rh}_{2} \mathrm{O}_{3}$ phase could be clearly identified on the $\mathrm{Rh} / \mathrm{ZSM}-5(30)$-IE sample, as shown in Fig. 3 (b). The EDS mapping of Rh/ZSM-5(30)-IE shown in Fig. 4 (b) also confirmed the high dispersion

213 of $\mathrm{Rh}$ in the ion exchanged sample. The $\mathrm{Rh}$ loading determined from EDS of the measured crystal is $2140.44 \pm 0.21$ wt.\% which is in reasonable agreement with the result from ICP-OES $(0.294 \pm 0.015$ wt.\%).

215 This suggests that the highly dispersed state seen in Figs. 3 (b) and 4 (b) is representative of the entire Rh/ZSM-5(30)-IE sample. 


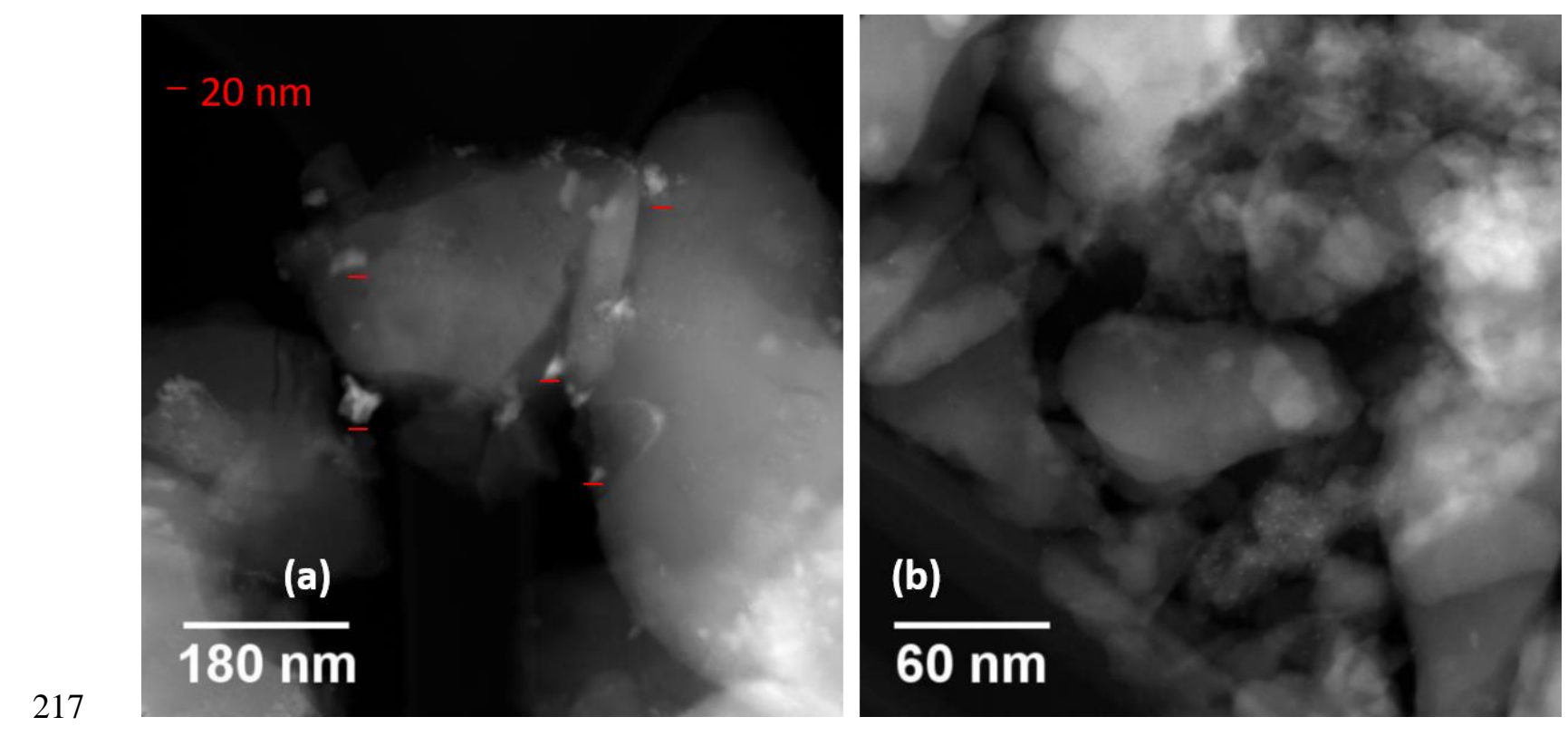

218 Fig. 3. HAADF-STEM images of (a): 2 wt.\% Rh/ZSM-5(280) and (b): Rh/ZSM-5(30)-IE. The red 219 lines in (a) represents $20 \mathrm{~nm}$. Fig. 3(a) reproduced with permission from Zhang et al. ${ }^{13}$. Copyright 2020, American Chemical Society.
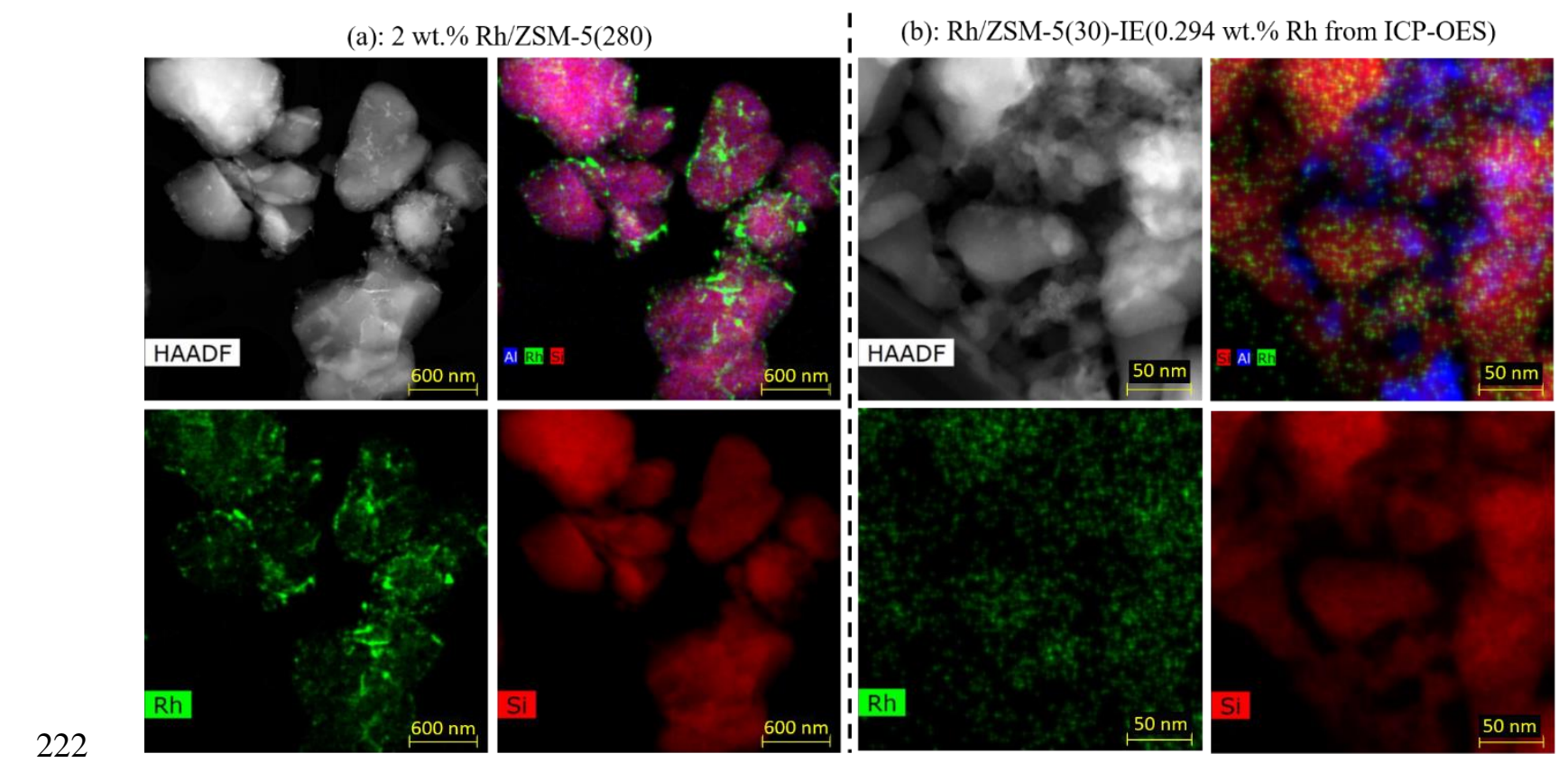

(b): Rh/ZSM-5(30)-IE(0.294 wt.\% Rh from ICP-OES)

Fig. 4. HAADF-STEM-EDS of (a): 2 wt.\% Rh/ZSM-5(280) and (b): Rh/ZSM-5(30)-IE. Fig. 4(a) reproduced with permission from Zhang et al. ${ }^{13}$. Copyright 2020, American Chemical Society. 
The CO-DRIFTS results illustrating the distribution of the $\mathrm{Rh}$ sites (i.e. $\mathrm{Rh}_{2} \mathrm{O}_{3}$ nanoparticles or single

$227 \mathrm{Rh}$ atoms) on the various supports are shown in Fig. 5. Fig. 5 shows that dicarbonyls, $\mathrm{Rh}(\mathrm{CO})_{2}$, were 228 formed on both isolated single $\mathrm{Rh}$ atoms $\left(\mathrm{a}_{\mathrm{s}} \text { and } \mathrm{a}_{\mathrm{a}} \text { at } 2115 \mathrm{~cm}^{-1} \text { and } 2048 \mathrm{~cm}^{-1}\right)^{24,31}$ and on oxidized $229 \mathrm{Rh}_{2} \mathrm{O}_{3}$ nanoparticles $\left(b_{\mathrm{s}} \text { and } \mathrm{b}_{\mathrm{a}} \text {, at 2084-2089 } \mathrm{cm}^{-1} \text { and 2010-2016 } \mathrm{cm}^{-1}\right)^{29,32,33}$. Fig. 5 (a) shows that the 230 ion exchanged $\mathrm{Rh} / \mathrm{ZSM}$-5(30)-IE catalyst only contains isolated single $\mathrm{Rh}$ atoms at the exchange sites in good agreement with the high dispersion evident from the XRD and TEM results. Oppositely Fig. 5 (b-d) shows that the fresh $\mathrm{Rh} / \mathrm{SiO}_{2}$ and $\mathrm{Rh} / \gamma-\mathrm{Al}_{2} \mathrm{O}_{3}$ catalysts and the $\mathrm{Rh} / \mathrm{ZSM}-5(280)$ catalyst on a ZSM5 support with a $\mathrm{SiO}_{2} / \mathrm{Al}_{2} \mathrm{O}_{3}$ ratio of 280 only contain $\mathrm{Rh}_{2} \mathrm{O}_{3}$ particles as evidenced by the symmetric and asymmetric stretches of $\mathrm{Rh}$ dicarbonyl $\mathrm{Rh}(\mathrm{CO})_{2}$ on oxide nanoparticles $\left(\mathrm{b}_{\mathrm{s}}\right.$ and $\left.\mathrm{b}_{\mathrm{a}}\right)$. This is in good agreement with the XRD results in Fig. 2 (c) and the STEM results in Fig. 3 (a) and Fig. 4 (a). For ZSM-5 zeolites with lower $\mathrm{SiO}_{2} / \mathrm{Al}_{2} \mathrm{O}_{3}$ ratios and hence more exchange sites the IR data in Fig. 5 (e-g) show that more $\mathrm{Rh}$ is dispersed as single atoms at the exchange sites and that the Rh exists as a mixture of nanoparticles and isolated Rh atoms. Fig. 5 (d-f) shows an increased relative intensity of single Rh atoms at exchange site $\left(a_{s}\right.$ and $a_{a}$ ) relative to $\mathrm{Rh}_{2} \mathrm{O}_{3}$ nanoparticle sites ( $b_{s}$ and $b_{a}$ ) with decreasing $\mathrm{SiO}_{2} / \mathrm{Al}_{2} \mathrm{O}_{3}$ ratio of the ZSM-5 zeolites. By using an Al-rich CHA structure zeolite, SSZ-13(24), Rh was also mainly dispersed to single $\mathrm{Rh}$ atoms at exchange sites with small amounts of nanoparticles as shown in Fig. 5 (g). To quantify the ratio of single atoms to nanoparticle sites the area ratios between the IR band for the symmetric $\mathrm{CO}$ stretch at single atom sites $\left(\mathrm{Rh}(\mathrm{CO})_{2, \mathrm{SA}}, \mathrm{a}_{\mathrm{s}}\right)$ and the band from symmetric $\mathrm{CO}$ stretch at nanoparticles $\left(\mathrm{Rh}(\mathrm{CO})_{2, \mathrm{NP}}, \mathrm{b}_{\mathrm{s}}\right)$ were calculated according to Eq. 1 and are shown in Fig. 6. The linear relationship between the $\mathrm{SiO}_{2} / \mathrm{Al}_{2} \mathrm{O}_{3}$ ratio of the zeolite and $\mathrm{Rh}(\mathrm{CO})_{2, \mathrm{SA}} / \mathrm{Rh}(\mathrm{CO})_{2, \mathrm{NP}}$ ratio in Fig. 6 illustrates that the dispersion of $\mathrm{Rh}$ atoms to exchange sites is

247 directly correlated to the availability of exchange sites in the zeolite which scales with the Al content 248 of the zeolites. 


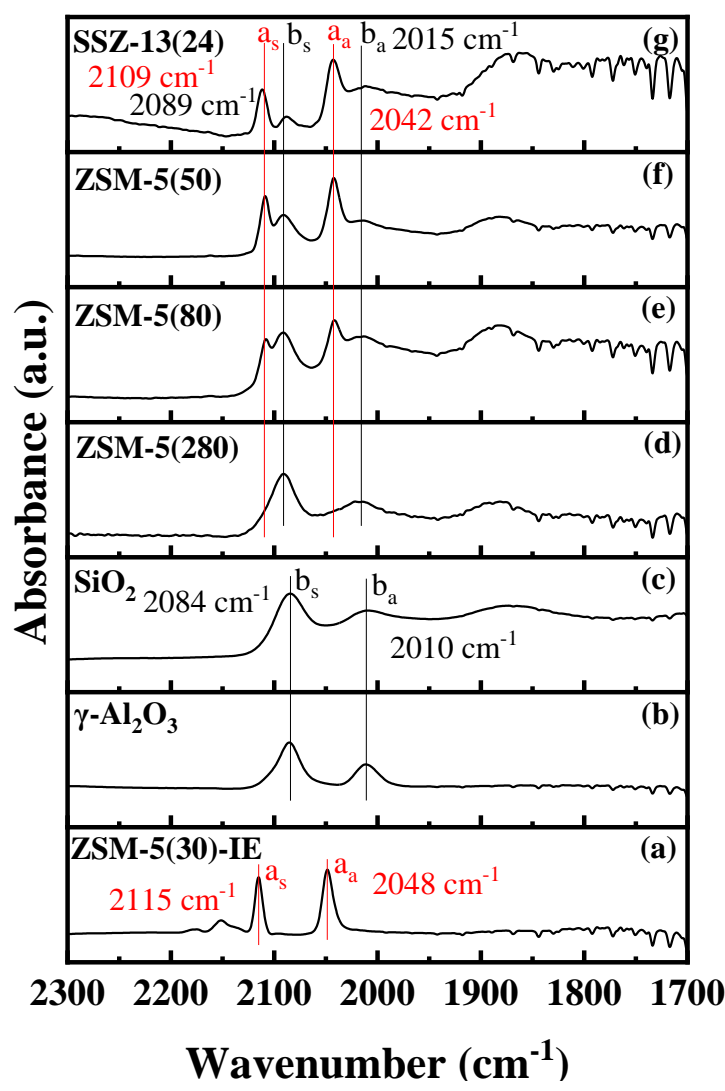

250 Fig. 5. CO-DRIFTS spectra obtained in He flush after $\mathrm{CO}$ chemisorption at $25^{\circ} \mathrm{C}$. (a): Rh/ZSM251 5(30)-IE; (b): 2 wt.\% Rh/ $\gamma-\mathrm{Al}_{2} \mathrm{O}_{3}$; (c): 2 wt.\% Rh/SiO ${ }_{2}$; (d): 2 wt.\% Rh/ZSM-5(280); (e): 2 wt.\% 252 Rh/ZSM-5(80); (f): 2 wt.\% Rh/ZSM-5(50); (g): 2 wt.\% Rh/SSZ-13(24). Data for Rh/SiO $2, \mathrm{Rh} / \gamma$ $\mathrm{Al}_{2} \mathrm{O}_{3}$, and $\mathrm{Rh} / \mathrm{ZSM}-5(280)$ from Zhang et al. ${ }^{13}$. 


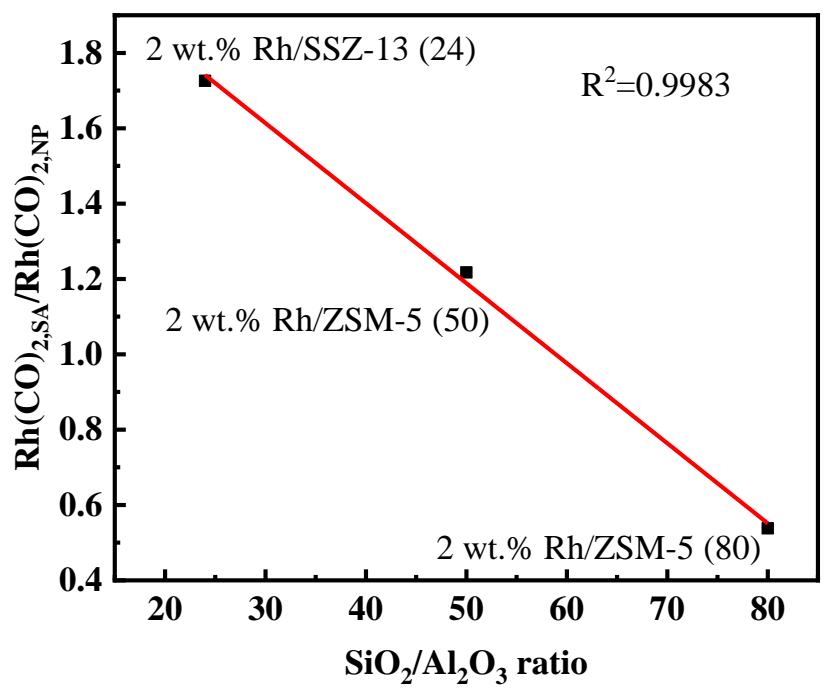

Fig. 6. The area ratio of the symmetric stretch of the $\mathrm{CO}$ bonded to single atom $\mathrm{Rh}$ site $\mathrm{Rh}(\mathrm{CO})_{2, \mathrm{SA}}$ to the symmetric stretch of the $\mathrm{CO}$ bonged to $\mathrm{Rh}_{2} \mathrm{O}_{3}$ nanoparticle $\mathrm{Rh}(\mathrm{CO})_{2, \mathrm{NP}}$ as a function of the $\mathrm{SiO}_{2} / \mathrm{Al}_{2} \mathrm{O}_{3}$ ratio of the zeolite support in the fresh $2 \mathrm{wt} . \% \mathrm{Rh}$ samples determined from Fig. 5.

The characterization of the Rh based catalysts by XRD, HAADF-STEM-EDS, and CO-DRIFTS thus provides a relatively consistent picture. For $\mathrm{SiO}_{2}, \gamma-\mathrm{Al}_{2} \mathrm{O}_{3}$ and the most Si-rich ZSM-5(280) zeolite the rhodium only exists in the form of $\mathrm{Rh}_{2} \mathrm{O}_{3}$ nanoparticles. For the ZSM-5 samples with higher Al-content the rhodium exists as a mixture of oxide nanoparticles and single $\mathrm{Rh}$ atoms at exchange sites, and the relative amount of $\mathrm{Rh}$ at exchange sites scales with the number of available exchange sites. Based on the absence of a continuous $\mathrm{Rh}_{2} \mathrm{O}_{3}$ phase in STEM-EDS investigations (Fig. 4 (b)) and the exclusive identification of single atom sites in DRIFTS measurements (Fig. 5 (a)) it is concluded that Rh/ZSM5(30)-IE only contains single $\mathrm{Rh}$ atoms at the exchange sites of the zeolite. Using the active site density on $\mathrm{Rh}_{2} \mathrm{O}_{3}$ estimated from methanol chemisorption by Badlani and Wachs, ${ }^{34}$ and the $\mathrm{Rh}_{2} \mathrm{O}_{3}$ nanoparticle size of 10-20 nm in the $2 \mathrm{wt} . \% \mathrm{Rh} / \mathrm{ZSM}-5(280)$ sample as determined from the STEM results in Fig. 3 (a) the concentration of active sites in this sample should be in the order of $15-29 \mu \mathrm{mol} / \mathrm{g}_{\text {cat. }}$ The ionexchanged $\mathrm{Rh} / \mathrm{ZSM}-5(30)$ catalyst contains only $0.294 \pm 0.015 \mathrm{wt} . \% \mathrm{Rh}$, but the $\mathrm{Rh}$ is exclusively present as single atom sites. Taking each single $\mathrm{Rh}$ atom to be an active site this translates into a 
concentration of active sites of $29 \mu \mathrm{mol} / \mathrm{g}_{\text {cat. }}$ Given the similarity in site concentration the differences in activity between the two samples should therefore reflect the differences in turnover frequencies of the two types of sites - i.e. $\mathrm{Rh}_{2} \mathrm{O}_{3}$ nanoparticle sites and single atom sites.

\subsection{Activity for $\mathrm{CH}_{4}$ oxidation}

The catalytic activity of the $\mathrm{Rh}$ based catalysts for $\mathrm{CH}_{4}$ oxidation in different reaction atmospheres is shown in the form of light-off curves in Fig. 7, and the temperature for $50 \% \mathrm{CH}_{4}$ conversion $\left(\mathrm{T}_{50}\right)$ for the catalysts under different conditions is listed in Table 2. A fresh catalyst sample was loaded for the activity measurement in each atmosphere. For the feeds without $\mathrm{SO}_{2}$ only the conversion during heating (so-called $1^{\text {st }}$ run) is shown in Fig. 7, while the conversion during cooling is shown in Figs. S2 and S3 in the Supporting Information. For the $\mathrm{SO}_{2}$-containing feed the data for both heating ( $1^{\text {st }}$ run) and cooling ( $2^{\text {nd }}$ run) are shown. Fig. 7 ( $a$ and $b$ ) and Table 2 show the catalytic activity in the absence of $\mathrm{SO}_{2}$ and here the most active sample is $\mathrm{Rh} / \mathrm{ZSM}-5(280)$, which according to Fig. 5 only has Rh in the form of $\mathrm{Rh}_{2} \mathrm{O}_{3}$ particles. The least active sample is the ion-exchanged $\mathrm{Rh} / \mathrm{ZSM}-5$ (30)-IE sample, where rhodium initially is exclusively present in the form of $\mathrm{Rh}$ atoms at zeolite exchange sites. As the $\mathrm{Rh} / \mathrm{ZSM}-5(280)$ and $\mathrm{Rh} / \mathrm{ZSM}-5(30)$-IE are estimated to have a similar concentration of surface sites this strongly suggests that sites on $\mathrm{Rh}_{2} \mathrm{O}_{3}$ particles are far more active than single $\mathrm{Rh}$ atoms. The remaining zeolite supported samples, which initially have rhodium in a mixture of nanoparticle and single atom forms, exhibit intermediate activity. The difference in activity between particle and single atom sites are likely to arise from the underlying differences in electronic structure. The single atom sites are likely to be oxygen deficient under reaction conditions, possibly because they are occupied by stable CO species, ${ }^{35}$ and this is likely to lower their activity in a Mars van Krevelen type reaction mechanism. The lower activity of the Rh single atom sites may contribute to their higher selectivity to partial oxidation products such as methanol under certain conditions. ${ }^{24}$ The significantly lower activity of single atom sites compared to nanoparticle sites for $\mathrm{CH}_{4}$ oxidation was also reported for $\mathrm{Pd}$ catalysts. ${ }^{18,36,37}$ The conversion for the Rh/ZSM-5(30)-IE catalyst is improved significantly during the subsequent cooling ( $2^{\text {nd }}$ run), and the conversion is shifted ca. $25^{\circ} \mathrm{C}$ down in temperature (Fig. S2 in 
the Supporting Information). Characterization of the spent Rh/ZSM-5(30)-IE catalyst by HAADFSTEM (Fig. 8 and Fig. S6) clearly illustrates that agglomeration of the Rh single atoms into small $(<5$ $\mathrm{nm})$ nanoparticles has occurred during operation. The higher activity during cooling ( $2^{\text {nd }}$ run $)$ compared to heating ( $1^{\text {st }}$ run) for this sample is attributed to a higher activity of the $\mathrm{Rh}_{2} \mathrm{O}_{3}$ particles that have formed by agglomeration of single $\mathrm{Rh}$ atoms during the heating ( $1^{\text {st }}$ run). These results indicate a tendency to partial agglomeration during operation that can explain why the activity of the zeolite supported samples with a mixture of particle and single atom sites does not correlate fully to the initial dispersion illustrated in Fig. 6.
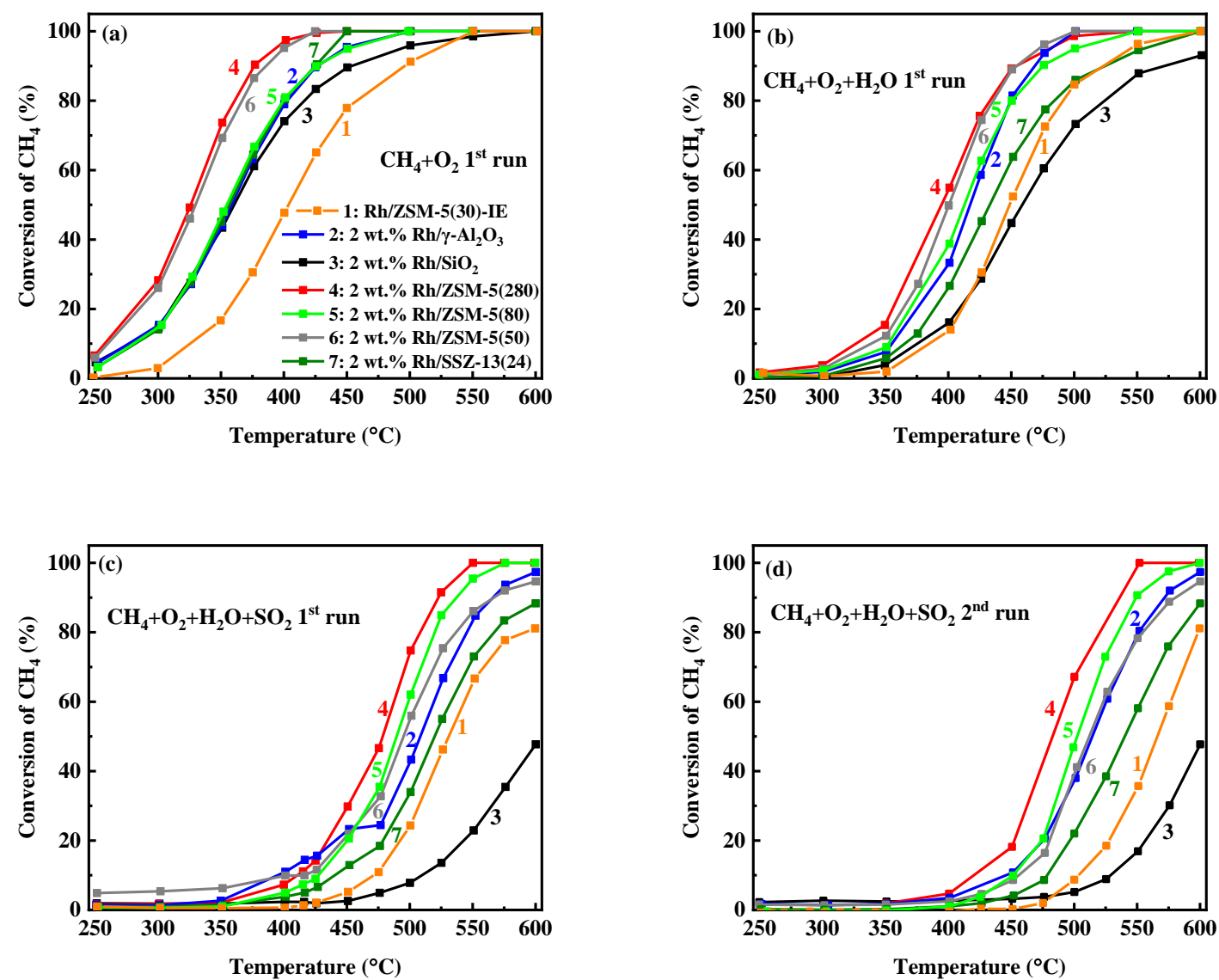

Fig. 7. Conversion of $\mathrm{CH}_{4}$ on Rh based catalysts in different atmospheres. (a): $1^{\text {st }}$ run in $\mathrm{CH}_{4}+\mathrm{O}_{2}$; (b): $1^{\text {st }}$ run in $\mathrm{CH}_{4}+\mathrm{O}_{2}+\mathrm{H}_{2} \mathrm{O} ;\left(\right.$ c): $1^{\text {st }}$ run in $\mathrm{CH}_{4}+\mathrm{O}_{2}+\mathrm{H}_{2} \mathrm{O}+\mathrm{SO}_{2} ;$ (d): $2^{\text {nd }}$ run in $\mathrm{CH}_{4}+\mathrm{O}_{2}+\mathrm{H}_{2} \mathrm{O}+\mathrm{SO}_{2} .1$ : 
Fig. 7 (b) and Table 2 show that in the presence of 5 vol. $\% \mathrm{H}_{2} \mathrm{O}$ there is a lower activity for all the supports, and $\mathrm{T}_{50}$ is shifted ca. $60{ }^{\circ} \mathrm{C}$ up in temperature. Such inhibition by $\mathrm{H}_{2} \mathrm{O}$ has also been observed previously for both $\mathrm{Rh}$ and Pd catalysts. ${ }^{13,38,39}$ This is partly attributable to a competitive adsorption by OH formed from $\mathrm{H}_{2} \mathrm{O}$. For Si-rich Rh/ZSM-5(280) the water inhibition is completely reversible, ${ }^{13}$ and no gradual deactivation was seen here during a stability test at $475^{\circ} \mathrm{C}$ for $15 \mathrm{~h}$ (Fig. S4 in the Supporting Information). However, for the Al-rich zeolites the stability is also affected (Fig. S4) with a clear continuous deactivation over time, especially for the Rh/ZSM-5(30)-IE and Rh/SSZ-13(24) catalysts with the highest Al-content in the zeolite. The stronger inhibition for Al-rich zeolite supports has also been observed for zeolite-supported Pd catalysts and has been attributed to changes in hydrophobicity with proton content, which makes more proton-rich zeolites more hydrophilic and thus more susceptible to the adverse effects of water. ${ }^{18-20,22}$ Given that the single atom sites are found to be less active and favored by a higher $\mathrm{Al}$ content this gradual loss of activity for Al-rich zeolites could be due to a watermediated dispersion into single atom species. The results in Fig. 7 (a and b) show that $\mathrm{Rh} / \gamma-\mathrm{Al}_{2} \mathrm{O}_{3}$ and $\mathrm{Rh} / \mathrm{SiO}_{2}$ are of intermediate activity despite having the rhodium entirely in the more active nanoparticle form, which would indicate that there is a beneficial support effect of the structured zeolite support. $\mathrm{Rh} / \mathrm{SiO}_{2}$ exhibits a modest activity in the absence of $\mathrm{H}_{2} \mathrm{O}$ (Fig. 7 (a)), but is strongly inhibited by the presence of $\mathrm{H}_{2} \mathrm{O}$ in the feed and becomes the least active catalyst when water is present. The strong inhibition by $\mathrm{H}_{2} \mathrm{O}$ for $\mathrm{SiO}_{2}$ as a support was also reported for $\mathrm{CH}_{4}$ oxidation on $\mathrm{Pd}^{40}$ This suggests the existence of specific interactions between water and the amorphous silica support that are highly detrimental to the catalytic activity. The $\mathrm{Rh} / \mathrm{SiO}_{2}$ catalyst also experienced a continuous gradual deactivation in the presence of $\mathrm{H}_{2} \mathrm{O}$, which was not seen for the Si-rich zeolite supports (Supporting Information Fig. S4). An Si-rich zeolite support is thus able to avoid the stronger inhibition occurring for both amorphous $\mathrm{SiO}_{2}$ and Al-rich zeolites. 


\begin{tabular}{lcccc}
\hline \multirow{2}{*}{ Catalysts } & \multicolumn{4}{c}{$\mathrm{T}_{50}\left({ }^{\circ} \mathrm{C}\right)^{\mathrm{b}}$} \\
\cline { 2 - 5 } & $\mathrm{CH}_{4}+\mathrm{O}_{2}$ & $\mathrm{CH}_{4}+\mathrm{O}_{2}+\mathrm{H}_{2} \mathrm{O}$ & $\mathrm{CH}_{4}+\mathrm{O}_{2}+\mathrm{H}_{2} \mathrm{O}+\mathrm{SO}_{2}$ \\
\cline { 2 - 5 } & $1^{\text {st }}$ run & $1^{\text {st }}$ run & $1^{\text {st }}$ run & $2^{\text {nd }}$ run \\
\hline $\mathrm{Rh} / \mathrm{ZSM}-5(30)-\mathrm{IE}(0.294 \text { wt.\% })^{\mathrm{a}}$ & 404 & 445 & 531 & 567 \\
2 wt.\% Rh/ $\gamma-\mathrm{Al}_{2} \mathrm{O}_{3}$ & 358 & 418 & 509 & 515 \\
2 wt.\% Rh/SiO & & 460 & $>600$ & $>600$ \\
2 wt.\% Rh/ZSM-5(280) & 361 & 395 & 478 & 483 \\
2 wt.\% Rh/ZSM-5(80) & 326 & 412 & 570 & 574 \\
2 wt.\% Rh/ZSM-5(50) & 355 & 401 & 495 & 513 \\
2 wt.\% Rh/SSZ-13(24) & 330 & 433 & 520 & 540 \\
\hline$: \mathrm{The}$ & 357 & & & \\
\hline
\end{tabular}

a: The weight loading of Rh/ZSM-5(30)-IE was determined by ICP-OES.

b: The $\mathrm{T}_{50}$ was calculated by interpolation between the $\mathrm{CH}_{4}$ conversions at two adjacent temperatures.
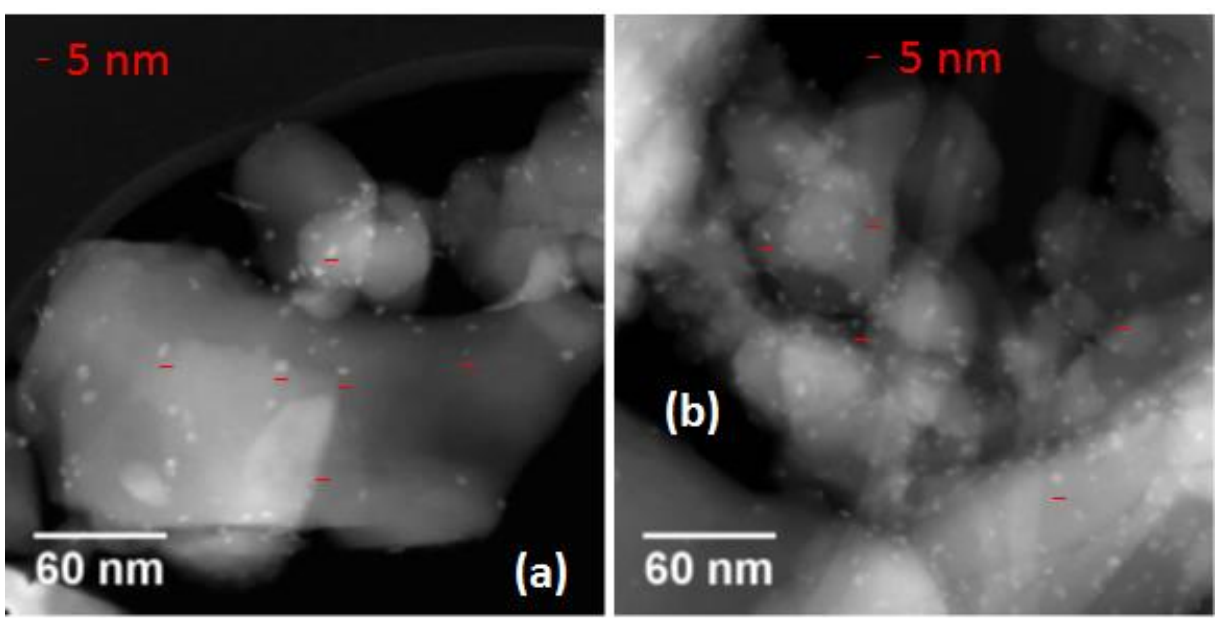

Fig. 8. HAADF-STEM images of spent Rh/ZSM-5(30)-IE. (a): after $\mathrm{CH}_{4}$ oxidation in $\mathrm{CH}_{4}+\mathrm{O}_{2}$ atmosphere; (b) after $\mathrm{CH}_{4}$ oxidation in $\mathrm{CH}_{4}+\mathrm{O}_{2}+\mathrm{H}_{2} \mathrm{O}$ atmosphere. EDS analysis can be seen in Figs. S6 and S7 in the Supporting Information. The red lines represent $5 \mathrm{~nm}$. The STEM picture of the fresh 
In the presence of both $5 \mathrm{vol} . \% \mathrm{H}_{2} \mathrm{O}$ and $20 \mathrm{ppm} \mathrm{SO}_{2}$ the catalytic activity is lowered further, and the oxidation is shifted to a higher temperature as shown in Fig. 7 (c) and (d). This is attributed to the formation of sulfate-type species on the active phase that block the active sites. ${ }^{13}$ In the initial period of $\mathrm{SO}_{2}$ exposure during the $1^{\text {st }}$ run the more Al-rich samples, particularly $\mathrm{Rh} / \gamma-\mathrm{Al}_{2} \mathrm{O}_{3}$ and $\mathrm{Rh} / \mathrm{ZSM}-5(50)$, are more active. It is well-established that the surface of $\mathrm{Al}_{2} \mathrm{O}_{3}$ takes up $\mathrm{SO}_{2}$ and becomes sulfated. ${ }^{12,41-}$ 46 The higher initial activity on the $\mathrm{Al}_{2} \mathrm{O}_{3}$ support is attributed to this initial $\mathrm{SO}_{2}$ uptake by the $\mathrm{Al}_{2} \mathrm{O}_{3}$ sites that protects the active phase from $\mathrm{SO}_{2}$ until the support is saturated. During cooling $\left(2^{\text {nd }}\right.$ run in Fig. 7 (d)) a stable activity level (Fig. S5 (b)) indicates that the $\gamma-\mathrm{Al}_{2} \mathrm{O}_{3}$ support has been saturated, whereby the full impact of $\mathrm{SO}_{2}$ on the active phase becomes visible, and here a strong deactivation is also observed for the $\mathrm{Rh} / \gamma-\mathrm{Al}_{2} \mathrm{O}_{3}$ sample. Fig.7 (d) shows that the more $\mathrm{Al}$ rich zeolites are relatively more affected by the presence of $\mathrm{SO}_{2}$. This is most clearly seen for the $\mathrm{Rh} / \mathrm{ZSM}-5(50)$ sample, which is almost as active as $\mathrm{Rh} / \mathrm{ZSM}-5(280)$ in the $\mathrm{SO}_{2}$-free atmospheres, but significantly less active in the presence of $\mathrm{SO}_{2}$. An explanation could be that some sulfation occurs for the more Al-rich zeolites in the same way as for the amorphous $\gamma-\mathrm{Al}_{2} \mathrm{O}_{3}$ and that this sulfation has negative implications for the performance of the active phase. ${ }^{18,46}$ Previous EDS mapping of elemental distribution in Rh/ZSM-5 after operation in an $\mathrm{SO}_{2}$ containing atmosphere did indicate some correlation between $\mathrm{Al}$ and sulfur, which could suggest that sulfur uptake occurs at the $\mathrm{Al}$ sites. ${ }^{13}$ More Al-rich zeolites are thus likely to take up greater amounts of sulfur on the support. catalyst, provide the best performance. The activity of $2 \mathrm{wt} . \% \mathrm{Rh} / \mathrm{ZSM}-5(280)$ was found to stable over time in the presence of $\mathrm{SO}_{2}$ and $\mathrm{H}_{2} \mathrm{O}$ as indicated by a limited $\left(5^{\circ} \mathrm{C}\right)$ shift for $\mathrm{T}_{50}$ between the $1^{\text {st }}$ and $2^{\text {nd }}$ runs after time on stream in $\mathrm{SO}_{2}$ for around $20 \mathrm{~h}$ (Table 2 and Fig. 7 (c) and (d)) as well as the stable conversion of $\mathrm{CH}_{4}$ during the $15 \mathrm{~h}$ stability test at $450{ }^{\circ} \mathrm{C}$ and $500{ }^{\circ} \mathrm{C}$ (Fig. S5 in the Supporting Information). The relatively sulfur tolerant behavior of Rh-catalysts for methane oxidation has previously been correlated to the ability of moist, bulk Rh sulfate to release part of their sulfur at lower temperatures. ${ }^{13}$ 

as the most active sample. As discussed, this can be attributed to the silica rich zeolite, which minimizes the formation of less active Rh single atom sites, minimizes the water inhibition that occurs for amorphous $\mathrm{SiO}_{2}$ and the more $\mathrm{Al}$ rich supports and avoids the negative effects of $\mathrm{SO}_{2}$ that occur for both Al-rich zeolites and $\gamma-\mathrm{Al}_{2} \mathrm{O}_{3}$.

\section{Conclusion}

The influence of the support has been investigated for Rh-based catalysts employed for total oxidation of $\mathrm{CH}_{4}$ using both amorphous $\mathrm{SiO}_{2}$ and $\gamma-\mathrm{Al}_{2} \mathrm{O}_{3}$ and $\mathrm{ZSM}-5\left(\mathrm{SiO}_{2} / \mathrm{Al}_{2} \mathrm{O}_{3}=280,80\right.$, and 50) and SSZ$13\left(\mathrm{SiO}_{2} / \mathrm{Al}_{2} \mathrm{O}_{3}=24\right)$ zeolites. A series of $2 \mathrm{wt} . \% \mathrm{Rh}$ catalysts on the various supports were prepared by incipient wetness impregnation and a catalyst containing $0.294 \pm 0.015 \mathrm{wt} . \% \mathrm{Rh}$ was prepared by ion exchange. The support was found to have a strong impact on both the speciation of the $\mathrm{Rh}$ and the catalytic activity, as the support influences the distribution of $\mathrm{Rh}$ between $\mathrm{Rh}_{2} \mathrm{O}_{3}$ nanoparticle sites and single atom sites. On $\mathrm{SiO}_{2}, \gamma-\mathrm{Al}_{2} \mathrm{O}_{3}$ and the most $\mathrm{Si}$-rich $\mathrm{ZSM}-5(280)$ zeolite $\mathrm{Rh}$ is only present as $\mathrm{Rh}_{2} \mathrm{O}_{3}$ particles, but on the more Al-rich zeolite supports a fraction of the $\mathrm{Rh}$ is dispersed as single atoms on the zeolite exchange sites. The fraction of $\mathrm{Rh}$ at exchange sites in the fresh catalyst scales with the Al-content of the zeolites as expected from the increased number of exchange sites. However, the ion-exchanged sample clearly shows that there is a tendency for agglomeration of single atom sites into particles during the methane oxidation. This means that the site distribution of the working catalyst may differ from that of the fresh catalyst.

For $\mathrm{CH}_{4}$ oxidation with and without the presence of 5 vol.\% $\mathrm{H}_{2} \mathrm{O}$ the highest catalytic activity is obtained for the Rh/ZSM-5(280) sample containing only rhodium in the nanoparticle form and the lowest activity occurs for the ion exchanged sample with Rh exclusively in the single atom form. The zeolite-supported samples containing a mixture of nanoparticle and single atom sites exhibit an intermediate activity. This tendency clearly illustrates that the oxide nanoparticles is the most active form of $\mathrm{Rh}$ for total oxidation of methane. The presence of water is inhibiting to all the catalysts, but 
most inhibiting for $\mathrm{Rh}_{2} \mathrm{O}_{3}$ on an amorphous $\mathrm{SiO}_{2}$ support, where $\mathrm{T}_{50}$ is shifted $100{ }^{\circ} \mathrm{C}$ up in temperature by the presence of 5 vol. $\% \mathrm{H}_{2} \mathrm{O}$. The lower activity of $\mathrm{Rh} / \mathrm{SiO}_{2}$ despite the $\mathrm{Rh}$ being in the more active nanoparticle form is attributed to this particularly strong inhibition from water that must be associated with the $\mathrm{SiO}_{2}$ support. With both amorphous $\mathrm{SiO}_{2}$ and $\mathrm{Al}$-rich supports water also affects the stability resulting in slow protracted deactivation, whereas Si-rich ZSM-5 zeolite supports do not yield this instability in the presence of water.

In the presence of both $\mathrm{H}_{2} \mathrm{O}$ and $\mathrm{SO}_{2}$ the most Al-rich supports are initially more active, but once a steady state has been reached the inhibition is stronger for the more Al-rich supports. This is most likely because the more Al-rich supports take up sulfur. This uptake delays the poisoning of the active phase, but at steady state the sulfur uptake by the more Al-rich supports appears to be detrimental to the performance of the active phase. These findings provide a basis for design of catalysts to be used in real engine exhaust gas conditions where both $\mathrm{H}_{2} \mathrm{O}$ and $\mathrm{SO}_{2}$ are present. The results illustrate that the optimal support is one that minimizes the interaction with both the reaction atmosphere and with the active phase. Too strong interactions with the active phase causes more $\mathrm{Rh}$ to be lost to the less active single atom sites and too strong interaction with the atmosphere causes the support to undergo interactions with $\mathrm{H}_{2} \mathrm{O}$ or $\mathrm{SO}_{2}$ that are detrimental to the performance of the active phase. The Si-rich ZSM-5(280) zeolite emerges as best support because the low number of exchange sites ensures the Rh is present in the more active oxide nanoparticle form, the low $\mathrm{Al}$ content prevents the sulfur uptake by

417 the support that inhibits the active phase at steady state and the structuring of the support prevents the particularly strong water induced inhibition that occurs with an amorphous $\mathrm{SiO}_{2}$ support.

\section{Supporting information}

421 XRD of $\mathrm{Rh} / \mathrm{ZSM}-5(30)-\mathrm{IE}$ and the pure support; activity of Rh based catalysts for $\mathrm{CH}_{4}$ oxidation; characterization of spent catalysts. 


\section{${ }_{424}$ Conflicts of interest}

There are no conflicts of interest to declare.

426

427

\section{Acknowledgements}

428

430

431

432

433

434

435

436 References

4371 A. Raj, Johnson Matthey Technol. Rev., 2017, 60, 228-235.

438

439

440

441

442

443

444

445

446 supports, and Haldor Topsoe for providing the SSZ-13 zeolite support.

This work is part of the Danish societal partnership, Blue INNOship and partly funded by Innovation Fund Denmark (IFD) under File No: 155-2014-10 and the Danish Maritime Fund. Additional funding is provided by the Technical University of Denmark (DTU) and Haldor Topsoe. The engine exhaust gas condition was provided by MAN Energy Solutions. The XRD, HAADF-STEM-EDS, ICP-OES measurements and analyses were carried out by Lars Fahl Lundegaard, Ramchandra R. Tiruvalam and Lars Frøsig Østergaard from Haldor Topsoe. We thank Saint Gobain for providing the $\gamma-\mathrm{Al}_{2} \mathrm{O}_{3}$ and $\mathrm{SiO}_{2}$ 
$4478 \quad$ M. Cargnello, J. J. D. Jaen, J. C. H. Garrido, K. Bakhmutsky, T. Montini, J. J. C. Gamez, R. J. $448 \quad$ Gorte and P. Fornasiero, Science., 2012, 337, 713-717.

4499 A. T. Gremminger, H. W. Pereira De Carvalho, R. Popescu, J. D. Grunwaldt and O. 450 Deutschmann, Catal. Today, 2015, 258, 470-480.

45110 M. Monai, T. Montini, M. Melchionna, T. Duchon, P. Kúš, C. Chen, N. Tsud, L. Nasi, K. C. 452 Prince, K. Veltruská, V. Matolín, M. M. Khader, R. J. Gorte and P. Fornasiero, Appl. Catal. B $453 \quad$ Environ., 2017, 202, 72-83.

45411 M. S. Wilburn and W. S. Epling, Emiss. Control Sci. Technol., 2018, 4, 78-89.

45512 N. Sadokhina, G. Smedler, U. Nylén, M. Olofsson and L. Olsson, Appl. Catal. B Environ., 2018, $456 \quad$ 236, 384-395.

457

13 Y. Zhang, P. Glarborg, K. Johansen, M. P. Andersson, T. K. Torp, A. D. Jensen and J. M. 458 Christensen, ACS Catal., 2020, 10, 1821-1827.

14 Y. Zhang, P. Glarborg, M. P. Andersson, K. Johansen, T. K. Torp, A. D. Jensen and J. M. 460 Christensen, Appl. Catal. B Environ., 2020, 277, 119176.

Y. Zhang, PhD Thesis, Technical University of Denmark, 2019.

I. Nova and E. Tronconi, Urea-SCR Technology for DeNOx After Treatment of Diesel Exhausts, Springer-Verlag New York, 2014. Commun., 2018, 9, 2545. 
47022 P. Losch, W. Huang, O. Vozniuk, E. D. Goodman, W. Schmidt and M. Cargnello, ACS Catal., $2019,9,4742-4753$.

47223 Y. Tang, Y. Li, V. Fung, D. Jiang, W. Huang, S. Zhang, Y. Iwasawa, T. Sakata, L. Nguyen, X. Zhang, A. I. Frenkel and F. F. Tao, Nat. Commun., 2018, 9, 1-11. 608. Hongling Guan, AICHE, 2017, 63, 2081-2088. 1224. 6487-6497.

N. D. Nielsen, J. Thrane, A. D. Jensen and J. M. Christensen, Catal. Letters, 2020, 150, 1427484 1433.

485

C. Y. Fang, S. Zhang, Y. Hu, M. Vasiliu, J. E. Perez-Aguilar, E. T. Conley, D. A. Dixon, C. Y. Chen and B. C. Gates, ACS Catal., 2019, 9, 3311-3321.

A. K. Smith, F. Hugues, A. Theolier, J. M. Basset, R. Ugo, G. M. Zanderighi, J. L. Bilhou, V. Bilhou-Bougnol and W. F. Graydon, Inorg. Chem., 1979, 18, 3104-3112.

A. Theolier, A. K. Smith, M. Leconte, J. M. Basset, G. M. Zanderighi, R. Psaro and R. Ugo, J. Organomet. Chem., 1980, 191, 415-424.

M. Badlani and I. E. Wachs, Catal. Letters, 2001, 75, 137-149. 
49336 E. D. Goodman, A. C. Johnston-Peck, E. M. Dietze, C. J. Wrasman, A. S. Hoffman, F. Abild-

494 Pedersen, S. R. Bare, P. N. Plessow and M. Cargnello, Nat. Catal., 2019, 2, 748-755.

49537 K. Okumura, E. Shinohara and M. Niwa, Catal. Today, 2006, 117, 577-583.

49638 Y. Zhang, P. Glarborg, M. Andersson, K. Johansen, T. K. Torp, A. D. Jensen and J. M.

497 Christensen, Appl. Catal. B Environ., , DOI:https://doi.org/10.1016/j.apcatb.2020.119176.

$49839 \quad$ R. Gholami, M. Alyani and K. Smith, Catalysts, 2015, 5, 561-594.

$49940 \quad$ K. Muto, N. Katada and M. Niwa, Appl. Catal. A Gen., 1996, 134, 203-215.

50041 T. Hamzehlouyan, C. Sampara, J. Li, A. Kumar and W. Epling, Appl. Catal. B Environ., 2014, $501 \quad \mathbf{1 5 2}-\mathbf{1 5 3}, 108-116$.

50242 T. Hamzehlouyan, C. S. Sampara, J. Li, A. Kumar and W. S. Epling, Appl. Catal. B Environ., $503 \quad 2016, \mathbf{1 8 1}, 587-598$.

50443 M. S. Wilburn and W. S. Epling, ACS Catal., 2019, 9, 640-648.

50544 X. Zi, L. Liu, B. Xue, H. Dai and H. He, Catal. Today, 2011, 175, 223-230.

50645 L. S. Escandón, S. Ordóñez, A. Vega and F. V. Díez, J. Hazard. Mater., 2008, 153, 742-750.

50746 I. C. Marcu and I. Săndulescu, J. Serbian Chem. Soc., 2004, 69, 563-569. 